\title{
Tectaria fuscipes (Wall. ex Bedd.) C. Chr. (Tectariaceae), a newly recorded taxon from Korea
}

\author{
Hye Woo Shin, Myoung Jun Kim ${ }^{1}$, Chung Keun $\mathrm{Oh}^{2}$ and Nam Sook Lee ${ }^{3 *}$ \\ Interdisciplinary Program of EcoCreative, The Graduate School, Ewha Womans University, Seoul 03760, Korea \\ ${ }^{1}$ Yeomiji Botanical Garden, Jeju 63535, Korea \\ ${ }^{2} 281$, Geomeunyeo-ro, Seogwipo 63604, Korea \\ ${ }^{3}$ Department of Life Science, Ewha Womans University, Seoul 03760, Korea
}

(Received 26 October 2017; Revised 6 December 2017; Accepted 22 December 2017)

\section{백록고사리(미늘창고사리과): 한국 미기록종}

\author{
신혜우 · 김명준 ${ }^{1}$ 오충근 ${ }^{2} \cdot$ 이남숙 ${ }^{3 *}$ \\ 이화여자대학교 대학원 에코크리에이티브 협동과정, ${ }^{1}$ 여미지식물원, \\ ${ }^{2}$ 제주도 서귀포시 검은여로 $281,{ }^{3}$ 이화여자대학교 생명과학과
}

\begin{abstract}
Tectaria fuscipes (Wall. ex Bedd.) C. Chr. (Baek-Rok-Go-Sa-Ri) is newly reported in Korea. This species belongs to the genus Tectaria Cav. of the family Tectariaceae Panigrahi. Thus far, no taxa of Tectariaceae have been reported in Korea. Tectaria fuscipes is characterized by its suberect to ascending rhizome, dimorphic or subdimorphic fronds, and free veins. The species was found on the southwestern slopes of Mt. Halla on Jeju Island, where it grows in sun near a small cave. It also occurs in southern China and in Taiwan. In Japan, eight species of the genus Tectaria have been reported, but T. fuscipes has yet to be recorded there. Jeju Island is the northeastern-most limit of the known range of this species.
\end{abstract}

Keywords: Tectaria fuscipes, Tectariaceae, newly recorded taxon

적 요: 한국에 백록고사리[Tectaria fuscipes (Wall. ex Bedd.) C. Chr.]를 처음으로 보고한다. 이 종은 한국에 서 보고된 바 없는 미늘창고사리과(Tectariaceae Panigrahi)의 미늘창고사리속(Tectaria Cav.)에 속한다. 백록고 사리는 거의 직립하거나 비스듬히 올라가는 지하경, 이형엽 또는 반이형협, 유리맥이 있는 특징이 있다. 이 종은 제주도 서귀포시 한라산 남서부 사면에 분포하고 있으며, 중국의 남부지역과 대만에서도 자생한다. 일본 에는 미늘창고사리속 식물 8 종이 보고되어 있으나 백록고사리는 아직 보고되지 않았다. 제주도는 지금까지 알 려진 백록고사리의 분포 지역 중 가장 최북동 지역이며, 그 서식처는 작은 수직동굴 내부로 한정되어 있다.

주요어: 백록고사리, 미늘창고사리과, 미기록과, 미기록속, 미기록종

Tectariaceae Panigrahi was accepted as an independent family in a revision of fern classification in 2006 (Panigrahi, 1986; Smith et al., 2006). The family Tectariaceae formed a large clade with Oleandraceae, Polypodiaceae, and Davalliaceae. It is the basal lineage among the four families of the clade (Smith et al., 2006). Tectariaceae has usually shortcreeping to ascending rhizomes with scales. The fronds are monomorphic to strongly dimorphic. The blades are pinnate, bipinnate, or decompound. The rachis and costae are usually covered by articulate multicellular hairs. The indusia are

*Author for correspondence: namsook@ewha.ac.kr 
reniform or peltate. The spores are of a brownish color and are monolete or monolete with various ornaments. (Smith et al., 2006; Sun et al., 2014). Within Tectariaceae, Tectaria is the largest genus and it is taxonomically confused (Cavanilles, 1799; Copeland, 1947). This genus contains 150-210 species that are mostly distributed in tropical areas (Tryon and Tryon, 1982; Holttum, 1991). Most members of the genus Tectaria have unlobed basal pinnae, but in some species the basal pinnae are lobed, in which case the basal basiscopic lobes or pinnule are the largest. The veins are copiously anastomosing, although some species have free veinlets (Sun et al., 2014). Since Tectaria has been generally accepted as a distinct genus (Underwood, 1906; Copeland, 1907; Ching, 1931; Christensen, 1934), its taxonomic delimitation has proved controversial (Ding et al., 2014). Molecular studies on plastid and nuclear markers of Tectaria strongly supported the monophyly (Ding et al., 2014; Zhang et al., 2016; Zhang et al., 2017). The most recent molecular data suggest that Tectaria is composed of four superclades and 12 major clades (Zhang et al., 2017).

Here, Tectaria fuscipes (Wall. ex Bedd.) C. Chr. of the family Tectariaceae is newly reported from Korea (Figs. 1, 2). The local name of the family and genus were given as "Mi-neulchang-go-sa-ri" based on the English common name of "Halberd fern". In botanical terminology, "Halberd" means arrowhead shaped with the basal lobes turned outward. Many Tectaria species have a halberd-shaped blade or pinna at the frond apex. "Halberd" is translated as "Mi-neul-chang" in Korean. "Mi-neul-chang" means a spear with two or threepronged strands ending like branches and "Go-sa-ri" means fern. The Korean name of T. fuscipes, "Baek-rok-go-sa-ri", means the white snow-covered slope where it was first discovered.

According to the molecular phylogeny of the genus Tectaria, T. fuscipes is included in the Ctenitopsis superclade and Ctenitopsis major clade (Zhang et al., 2017). Tectaria fuscipes has previously been treated as a synonym of T. paradoxa (Fée) Sledge (Sledge, 1972). On the other hand, Patil et al. (2014) distinguished $T$. fuscipes from $T$. paradoxa on account of its dimorphic fronds. However, partially monomorphic fronds were found in the population of Jeju Island, as in other studies (Wu et al., 2013; Sun et al., 2014) (Fig. 3). According to the frond type, $T$. fugipes of Jeju should be $T$. paradoxa, but the 13 commonly used morphological characters were all revealed as homoplastic in Tectaria in the recent phylogenetic studies (Ding et al., 2014; Zhang et al., 2017). This means that frond type is not a key character to distinguish $T$. fuscipes and $T$. paradoxa. The isotype specimen of Aspidium paradoxum (Herbier de l'Universite Montpellier II (MPU), MPU015614), which represents the basionym of $T$. paradoxa, differs morphologically from specimens of $T$. fuscipes collected on Jeju Island. Also, recent studies still maintain this synonymous name with insufficient information (Ding et al., 2014; Patil et al., 2014; Zhang et al., 2016; Zhang et al., 2017). Therefore, we use the name $T$. fugipes instead of $T$. paradoxa.

Several species of Tectaria have been reported from southern China (Guangxi, Guizhou, Hainan, Taiwan, Xizang, and Yunnan) and eight species have been reported in Japan (Iwatsuki et al., 1995; Wu et al., 2013). However, to date $T$. fuscipes has not been recorded in Japan. This species is also reported in India and most Southeast Asian countries: Cambodia, Indonesia, Myanmar, Nepal, Taiwan, Thailand, Vietnam (Ching, 1931; Holttum, 1988; Wu et al., 2013; Patil et al., 2014; Sun et al., 2014). In previous studies, the easternmost and northernmost distribution of the species was known to be Taiwan and Xizang, respectively. The new discovery on Jeju Island therefore represents a northeastern extension of its range, and suggests that $T$. fuscipes may occur in the southern part of Japan. Additionally, other species of Tectariaceae which are native to China, Japan, and Taiwan may yet be found in Korea. Tectaria fuscipes grows in full sun 3$4 \mathrm{~m}$ from the entrance of a small, humid cave. This cave is situated at 300-400 $\mathrm{m}$ above sea level on the southern slopes of Mt. Halla, and there is a distinct temperature difference across its entrance. This specific habitat is very limited, making T. fuscipes prone to disturbance and extirpation. Only ca. 50 individuals were seen in an area of approximately $3 \mathrm{~m}^{2}$. Careful research needs to be conducted to survey more suitable habitats of T. fuscipes and to conserve this rare species in Korea.

\section{Taxonomic Treatment}

\section{Tectariaceae Panigrahi}

Pantropical terrestrial herbs. Rhizome usually short-creeping to ascending, dictyostelic, bearing scales; petioles not abscising, with a ring of vascular bundles in cross-section; blades simple, pinnate, or bipinnate, sometimes decompound; indument of jointed, usually short stubby hairs on the axes, veins, and sometimes laminar tissue, especially on rachises and costae adaxially; veins free or often highly anastomosing, sometimes with included veinlets; indusia reniform or peltate (lost in several lineages); spores brownish, reniform, monolete, variously ornamented; $x=40$ (a few genera with $x=41$, some dysploids with $x=39$ ).

Selected reference: Smith, A. R., K. M. Pryer, E. Schuettpelz, P. Korall, H. Schneider, and P. G. Wolf. Taxon 55: 705-731, 2006. 


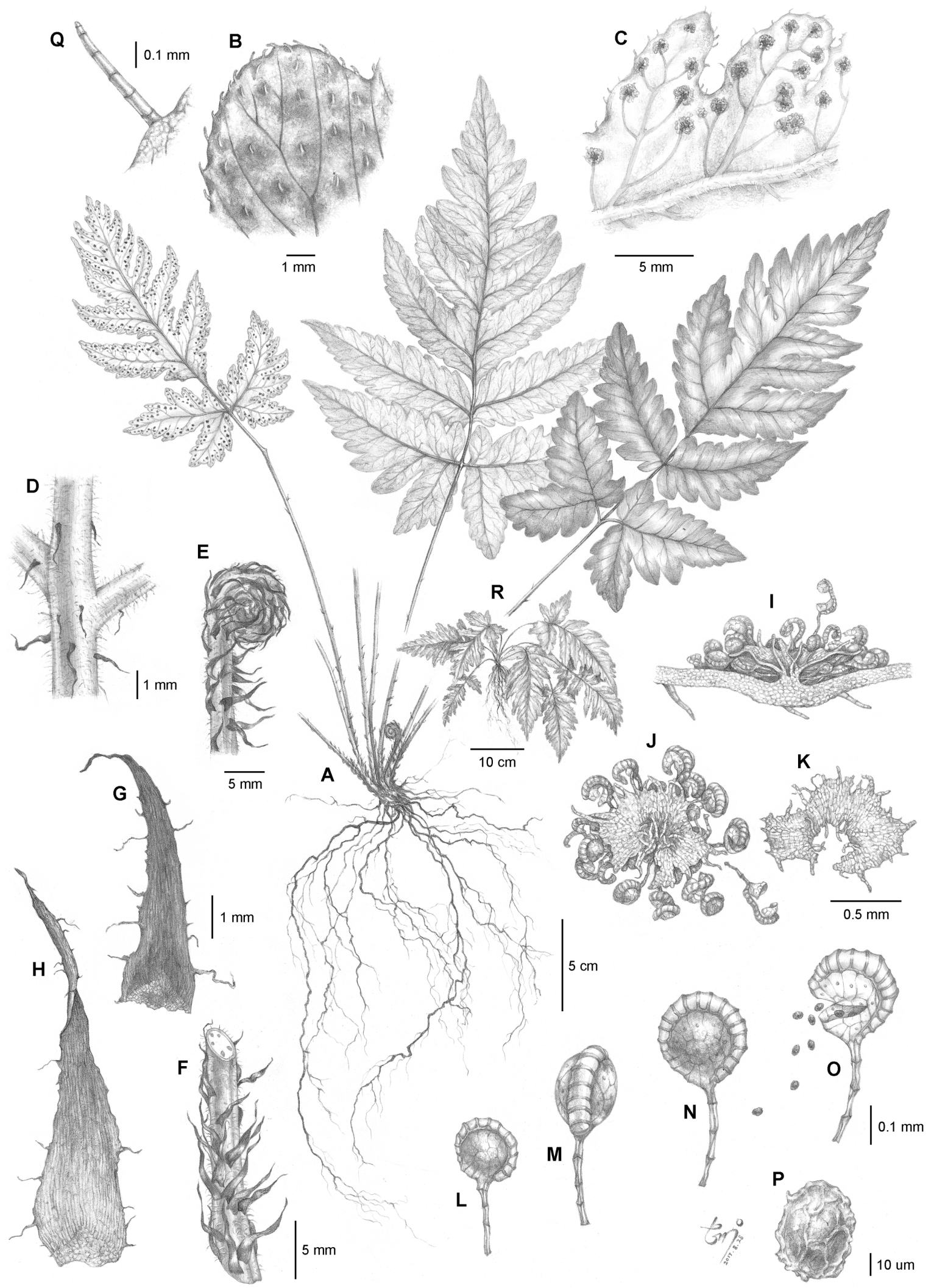

Fig. 1. Illustration of Tectaria fuscipes (Wall. ex Bedd.) C. Chr. A. Individual plant. B. Adaxial lobe of a trophophyll. C. Abaxial lobe of a sporophyll showing sori. D. Rachis. E. Fiddlehead. F. Lower portion of a stipe. G, H. Scales. I. Cross section of a sorus. J. frontal view of a sorus. K. Indusium. L-O. Development of a sporangium. P. Spore. Q. Hair. R. Habit. 

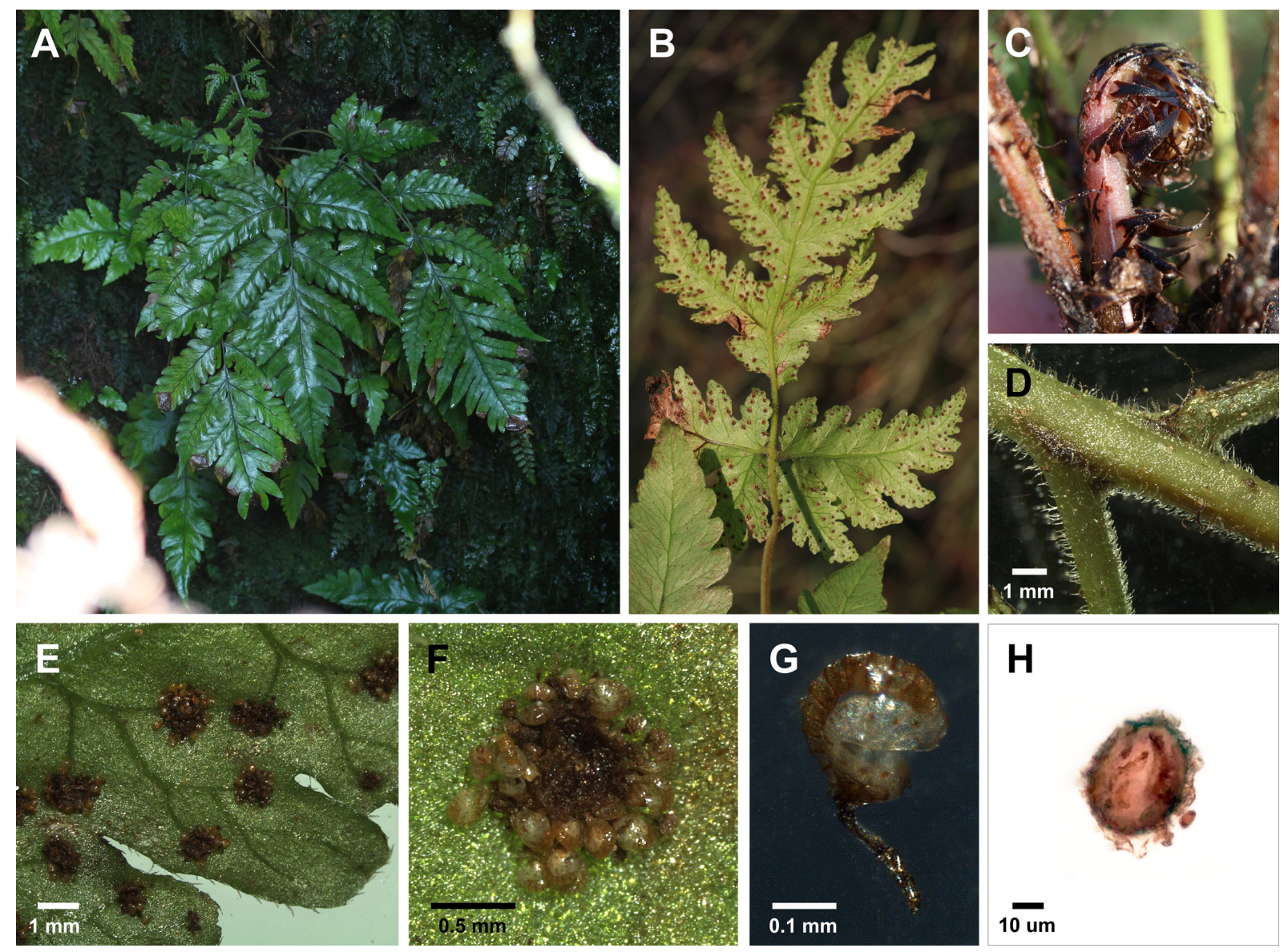

H

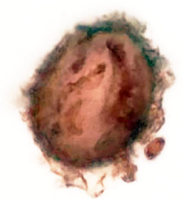

10 um

Fig. 2. Photographs of Tectaria fuscipes (Wall. ex Bedd.) C. Chr. A. Habitat of T. fuscipes. B. Abaxial surface of a sporophyll. C. Fiddlehead. D. Rachis. E. Abaxial lobe of a sporophyll showing sori. F. Sorus. G. Sporangium. H. Spore.
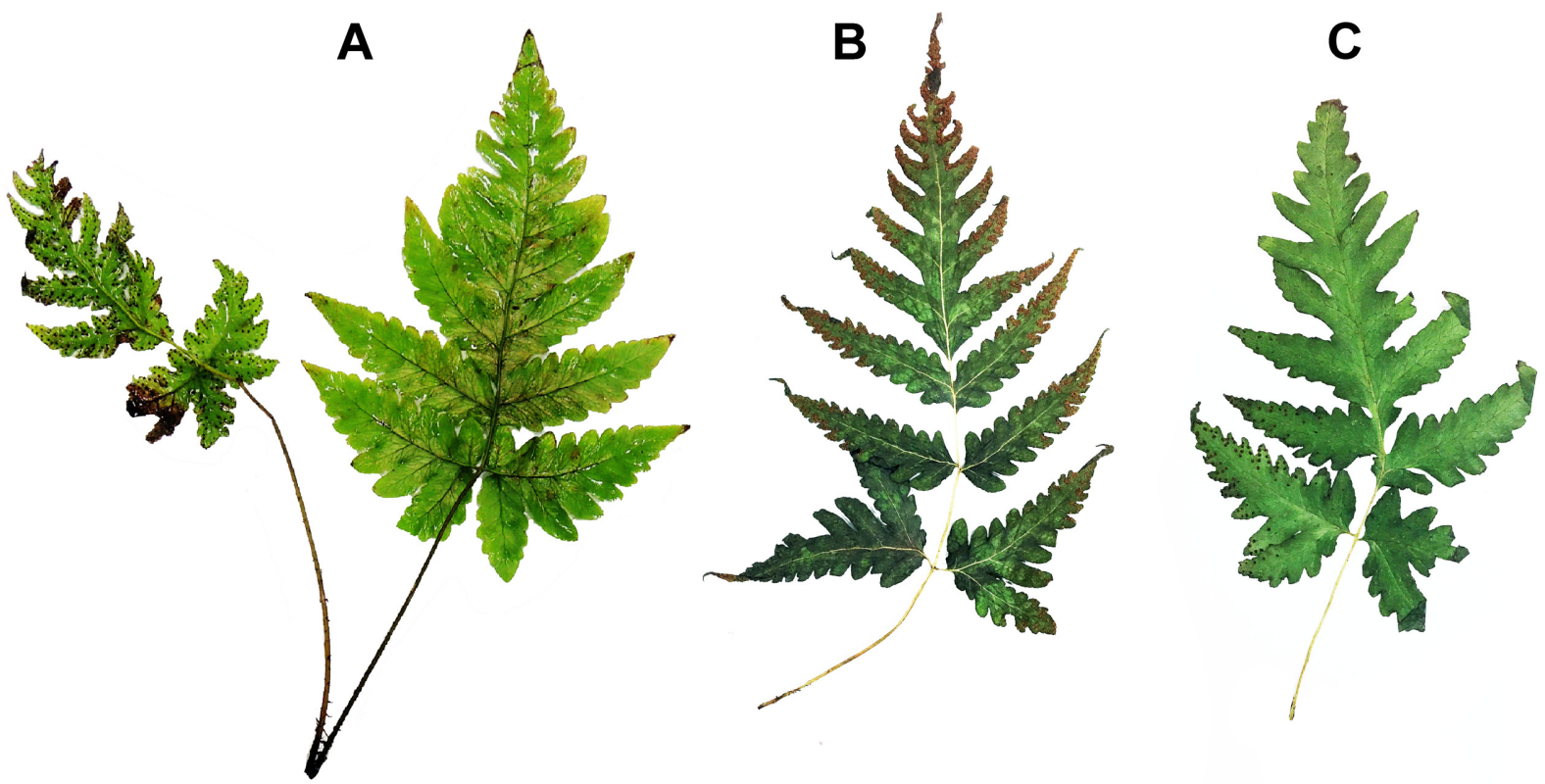

Fig. 3. Fronds of Tectaria fuscipes (Wall. ex Bedd.) C. Chr. A. Dimorphic fronds. B, C. Monomorphic fronds. 
Korean name: Mi-neul-chang-go-sa-ri-gwa (미늘창고사리 과) (신칭).

\section{Tectaria Cav.}

Plants terrestrial or lithophytic. Stems short-creeping to erect, stolons absent. Leaves monomorphic, evergreen. Petiole 3/4-3 times length of blade, base not swollen; vascular bundles more than 3, arranged in an arc, \pm round in cross section. Blade lanceolate to deltate or pentagonal, entire to 1-pinnate-pinnatifid [3-pinnate-pinnatifid], reduced distally to shallowly lobed or hastate apex, herbaceous to papery. Pinnae not articulate to rachis, segment margins entire to sinuate or shallowly lobed; proximal pinnae not or only slightly reduced, sessile to short-petiolulate, base equilateral or often inequilateral with prominent basiscopic lobe(s); costae adaxially rounded or shallowly grooved, grooves not continuous from rachis to costae; indument lacking or of multicellular hairs on costae abaxially, of multicellular hairs on costae adaxially. Veins reticulate, areoles with or without included veinlets. Sori in 1-several rows between midrib and margin, round; indusia peltate to round-reniform and with narrow sinus, persistent or caducous. Spores brownish, with inflated folds or wings. $x=40$.

Selected reference: Morton, C. V. 1966. Am. Fern J. 56: 120-137, 1966.

Korean name: Mi-neul-chang-go-sa-ri-sok (미늘창고사리 속) (신칭).

Tectaria fuscipes (Wall. ex Bedd.) C. Chr., Contr. U. S. Natl. Herb. 26: 290, 1931; Aspidium fuscipes Wall. ex Bedd., Suppl. Ferns Brit. Ind. 15, pl. 366, 1876; Lastrea fuscipes (Wall. ex Bedd.) Bedd., Handb. Ferns Brit. India. 243, 1883; Nephrodium fuscipes (Wall. ex Bedd.) C. B. Clarke, Symb. Sin. 6: 24, 1929; Ctenitopsis fuscipes (Wall. ex Bedd.) C. Chr., Notul. Syst. (Paris) 7: 87, 1938.

Nephrodium membranifolium var dimorpha C. B. Clarke, Trans. Linn. Soc. Lond., Bot. 1: 535, pl. 75, f. B C, 1880.

Pleocnemia membranifolia auct. non C. Presl: Bedd., Handb. Ferns Brit. India: 225, f. 115, 1883.

Aspidium membranifolium var. dimorphum (C.B. Clarke) Christ, J. Bot. (Morot) 19: 4, 62, 1905.

Ctenitopsis glabra Ching \& C. H. Wang, Acta Phytotax. Sin. 9: 370, 1964.

Korean name: Baek-rok-go-sa-ri (백록고사리).

Plant to $50 \mathrm{~cm}$ tall. Rhizome short, suberect to ascending; scales stiff, glossy, lanceolate, dark brownish or blackish, ca. $7 \mathrm{~mm}$ long. Fronds clustered, dimorphic or subdimorphic, fertile fronds narrower. Stipe ca. $15 \mathrm{~cm}$ long, deep stramineous or brownish, sparsely scaly, densely hairy; scales linear, ca. $2 \mathrm{~mm}$ long. Blade pinnate or 2pinnatifid to 2-pinnate, oblong-lanceolate or narrowly deltoid, 20-35 cm long, 10-20 cm wide, herbaceous, acuminate at apex, hairy throughout; pinnae 5-8 pairs; rachises and costae with sparse linear scales and densely hairs; basal pair of pinnae largest, more lobed, asymmetrically oblong-subdeltoid, stalks ca. $1 \mathrm{~cm}$; middle pinnae lanceolate or oblong-lanceolate, $6-10 \mathrm{~cm}$ long, 2$4 \mathrm{~cm}$ wide, base truncate or slightly cordate, apex acute to acuminate or caudate, lobed $1 / 3-1 / 2$ to costa; bearing large basal basiscopic pinnules, 4-6 cm long, 1.5-2.5 cm wide, pinnatifid or pinnatipartite. Veins free, pinnate in ultimate segments, veinlets simple or occasionally forked, reaching margin. Sori terminal on acroscopic branches of veinlets, medial in ultimate segments or rather irregularly dispersed on lower surface of pinnae; indusia roundreniform, hairy, persistent.

Voucher specimens: KOREA. Jeju-do: Seogwipo-si, Mt. Hallasan, alt. 320 m, 7 Mar 2017, M. J. Kim, C. K. Oh, N. S. Lee, \& J. H. So (2 sheets) (EWH); Seogwipo-si, Mt. Hallasan, alt. 320 m, 7 Sep 2017, M. J. Kim (3 sheets) (EWH).

Collection site: Pit cave on the southwestern slope of Mt. Hallasan (alt. 320 m), Seogwipo-si, Jeju-do, Korea.

Habitat: Tectaria fuscipes grows in sun close to the entrance of a cave. The cave has a lot of moisture and the width of the cave opening is about $3 \mathrm{~m}$. Tectaria fuscipes grows with Arachniodes rhomboidea and Crepidomanes sp. The vegetation in the vicinity consists of coppiced Mallotus japonicus, Rosa multiflora, Smilax china, etc.

Distribution: Cambodia, south China (Guangxi, Guizhou, Hainan, Xizang, and Yunnan), India (north east India including Assam and Sikkim and Western Ghats, Castle Rock), Indonesia (east Java and southwest Sulawesi), south Korea (Jeju Island), Myanmar, Nepal, Taiwan, Thailand, and Vietnam.

\section{Acknowledgments}

We would like to thank Dr. Stephan Gale (Kadoorie Farm and Botanic Garden) for the English proofreading of our manuscript. This research was supported by the BK21 Plus Program (Creative Academy of Eco Science, 31Z20130012990) funded by the Ministry of Education and National Research Foundation of Korea. 


\section{Literature Cited}

Cavanilles, A. 1799. Nuevos caractéres genéricos de los Helechos por Smith. Paper read at Anales de Historia Natural.

Ching, R. 1931. The studies of Chinese ferns VII, a revision of the genus Tectaria from China and Sikkim-Himalaya. Sinensia 2: 9-36.

Christensen, C. 1934. Index Filicum: sive enumeratio omnium generum specierumque Filicum et Hydropteridum. Supplementum Tertium: pro annis 1917-1933: H. Hagerup, 1934.

Copeland, E. B. 1907. A revision of Tectaria with special regard to the Philippine species. The Philippine Journal of Science 2: 409-418.

Copeland, E. B. 1947. Filicum Genera. Chronica Botanica Co. Waltham, Mass.

Ding, H.-H., Y.-S. Chao, J. R. Callado, and S.-Y. Dong. 2014. Phylogeny and character evolution of the fern genus Tectaria (Tectariaceae) in the Old World inferred from chloroplast DNA sequences. Molecular Phylogenetics and Evolution 80: $66-78$.

Holttum, R. E. 1988. Studies in the Fern Genera Allied to Tectaria Cav. VII. Species of Tectaria sect. Sagenia (Presl) Holttum in Asia excluding Malesia. Kew Bulletin 43: 475-489.

Holttum, R. E. 1991. Flora malesiana series II : Pteridophyta : Ferns and fern allies vol. 2, part 1. rijksherbarium/hortus botanicus.

Iwatsuki, K., D. E. Boufford, and H. Ohba. 1995. Flora of Japan: Pteridophyta and Gymnospermae. Vol. 1: Kodansha.

Panigrahi, G. 1986. Tectariaceae, fam. nov. to replace Aspidiaceae Mettenius ex Frank, nom. illeg. (Pteridophyta). Journal of Orissa Botanical Society 8: 41-42.

Patil, S., S. Yadav, and M. Dongare. 2014. Tectaria fuscipes (Wall. ex Bedd.) C. Chr. (Tectariaceae, Pteridophyta), a New Record for Southern India. The Journal of Japanese Botany 89: 186188.

Sledge, W. A. 1972. The tectarioid ferns of Ceylon. Kew Bulletin 407-424.

Smith, A. R., K. M. Pryer, E. Schuettpelz, P. Korall, H. Schneider, and P. G. Wolf. 2006. A classification for extant ferns. Taxon 55: 705-731.

Sun, B. Y., I. C. Hwang, M. O. Moon, and K. Nang. 2014. Biodiversity of Cambodia: Lycophytes and Ferns National Institute of Biological Resources, Ministry of Environment: Incheon.

Tryon, R. M., and A. F. Tryon. 1982. Ferns and allied plants: with special reference to tropical America: Springer-Verlag, New York.

Underwood, L. M. 1906. American Ferns-VI. Species Added to the Flora of the United States from 1900 to 1905 . Bulletin of the Torrey Botanical Club 33: 189-205.

Wu, Z., P. Raven, and D. Hong. 2013. Flora of China, vol. 2-3, Lycopodiaceae through Polypodiaceae: Beijing: Science Press.

Zhang, L., E. Schuettpelz, C. J. Rothfels, X.-M. Zhou, X.-F. Gao, and L.-B. Zhang. 2016. Circumscription and phylogeny of the fern family Tectariaceae based on plastid and nuclear markers, with the description of two new genera: Draconopteris and Malaifilix (Tectariaceae). Taxon 65: 723-738.

Zhang, L., X.-M. Zhou, D.-K. Chen, E. Schuettpelz, R. Knapp, N. T. Lu, T. T. Luong, M. T. Dang, Y.-F. Duan, and H. He. 2017. A global phylogeny of the fern genus Tectaria (Tectariaceae: Polypodiales) based on plastid and nuclear markers identifies major evolutionary lineages and suggests repeated evolution of free venation from anastomosing venation. Molecular Phylogenetics and Evolution. 